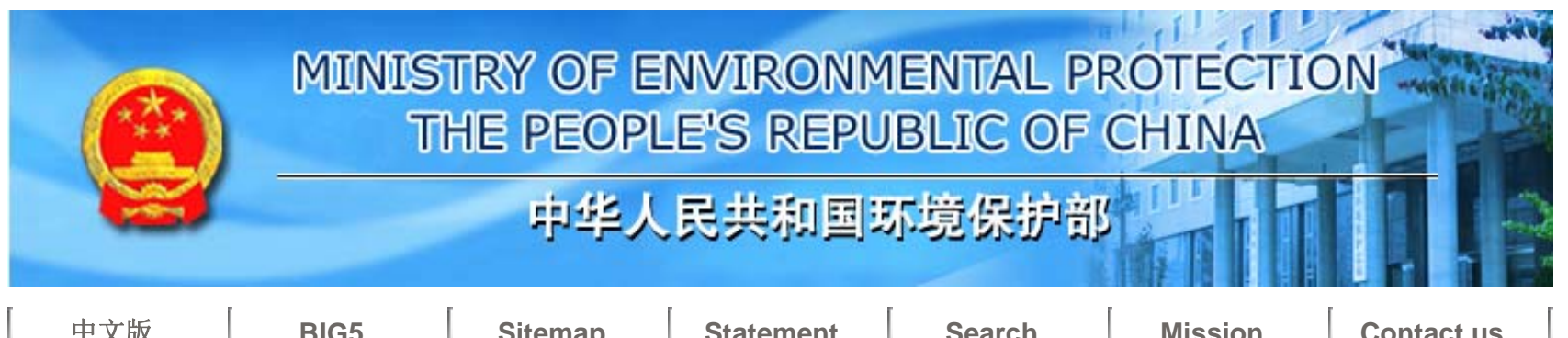
中文版
BIG5
Sitemap
Statement
Search
Mission
Contact us

Current Location:HOME->Policies and Regulations->Laws->Environmental Laws

\title{
Law of the People's Republic of China on the Prevention and Control of Environmental Pollution by Solid Waste
}

1995-10-30

Article type: Redistributed

(Adopted by the 16th Meeting of the Standing Committee of the Eighth National People's Congress

on October 30, 1995, promulgated by Order No.58 of the President of the People's Republic of China

on October 30, 1995, to be effective as of April 1, 1996)

\section{CHAPTER I GENERAL PRINCIPLES}

Article 1 To prevent the pollution of the environment by solid waste, ensure the good health of the public, and promote the development of socialist modernization, the following law is hereby established.

Article 2 This law applies to the prevention of environmental pollution caused by solid waste within the boundaries of the People's Republic of China.

It does not apply to the prevention of marine environmental pollution caused by solid waste or of environmental pollution caused by radioactive solid waste.

Article 3 To prevent pollution of the environment by solid waste, the state shall carry out a principle of reducing the production of solid waste, making full and rational use of solid waste, and safely disposing of solid waste.

Article 4 The state shall encourage and support clean production to reduce the creation of solid waste.

The state shall encourage and support the comprehensive utilization of resources, the full recovery and rational usage of solid waste, and the adoption of economic and technological policies and measures conducive to making comprehensive use of solid waste. Article 5 The state shall encourage and support measures for the centralized disposal of solid waste that are conducive to environmental protection.

Article 6 The People's governments at the county level or above shall coordinate the prevention of environmental pollution caused by solid waste with environmental protection plans and shall adopt economic and technological policies and measures conducive to the prevention of environmental pollution caused by solid waste.

http://english.mep.gov.cn/Policies_Regulations/laws/environmental_laws/200710/t200... 2009-10-7 
Article 7 The state shall encourage and support scientific research and technological development for the prevention of environmental pollution caused by solid waste, the promotion of advanced technologies for prevention, as well as the popularization of scientific knowledge for the prevention of environmental pollution caused by solid waste.

Article 8 The People's governments at different levels shall give awards to those units or individuals that make remarkable contributions to the prevention of environmental pollution caused by solid waste as well as in the related activities of making comprehensive use of solid waste.

Article 9 Every unit or individual has an obligation to protect the environment and has the right to report or bring charges against those units or individuals that are responsible for environmental pollution caused by solid waste.

Article 10 The administrative department under the State Council in charge of environmental protection shall exercise unified supervision and administration throughout the whole country over the prevention of environmental pollution caused by solid waste. The relevant departments under the State Council shall be in charge of the supervision and administration of the prevention of environmental pollution caused by solid waste within the limits of their own responsibilities.

The administrative departments under the local People's governments at the county level or above shall exercise unified supervision and administration over the prevention of environmental pollution caused by solid waste within the boundaries of the corresponding administrative division. The departments concerned under the People's governments at the county level or above shall be in charge of the supervision and administration of the prevention of environmental pollution caused by solid waste within the limits of their own responsibilities.

The administrative department under the State Council in charge of construction and the administrative departments in charge of the environment and public health under the local people's governments at the county level or above shall be in charge of the supervision and administration of the cleaning, collection, storage, transportation, and disposal of urban residential refuse.

CHAPTER II SUPERVISION AND ADMINISTRATION OF PREVENTION OF ENVIRONMENTAL POLLUTION CAUSED BY SOLID WASTES

Article 11 The administrative department under the State Council in charge of environmental protection shall establish a monitoring system for environmental pollution caused by solid waste, formulate unified monitoring standards, and organize a monitoring network in conjunction with other relevant departments.

Article 12 In constructing those projects that may produce industrial solid waste as well as those for storage and disposal of solid waste, the state administrative regulations for environmental protection in construction projects must be abided by.

http://english.mep.gov.cn/Policies_Regulations/laws/environmental_laws/200710/t200... 2009-10-7 
Reports on the effects of a construction project on the environment shall include an estimation of the pollution and other effects on the environment caused by the solid waste that is produced by the construction project, as well as the stipulation of measures for the prevention of environmental pollution, and shall be submitted to the administrative department in charge of environmental protection for approval in accordance with the procedures that are stipulated by the state. After the report on the environmental effects is ratified, the department in charge of examining and approving construction projects shall approve a feasibility study report or a design responsibility report for the project.

Article $13 \mathrm{~A}$ report on the effects of a construction project on the environment shall stipulate that the necessary facilities for the prevention of environmental pollution caused by solid waste must be designed, constructed, and put into operation in coordination with the principal part of the project. A construction project shall begin operation or use only after the facilities for the prevention of environmental pollution caused by solid waste are inspected and approved by the same department that examined and approved the report on the environmental effects. The facilities for the prevention of environmental pollution caused by solid waste shall be inspected and approved together with the principal part of the project.

Article 14 The administrative departments under the People's governments at the county level or above in charge of environmental protection and other supervisory and administrative departments in charge of the prevention of environmental pollution caused by solid waste shall have the right to conduct on-the-spot inspections of the units concerned with the prevention of environmental pollution caused by solid waste within their jurisdiction in accordance with their own responsibilities. The inspected units shall report the situation accurately and shall provide any necessary materials. The inspecting institutions shall maintain the technological and operational secrecy of the inspected units.

The inspecting personnel shall show their credentials while conducting on-the-spot inspections.

\section{CHAPTER III PREVENTION OF ENVIRONMENTAL POLLUTION CAUSED BY SOLID WASTES}

\section{Section 1 General Stipulations}

Article 15 The units and individuals that produce solid waste shall take measures to prevent or reduce the environmental pollution caused by solid waste.

Aticle 16 The units and individuals that collect, store, transport, utilize, or dispose of solid waste shall take precautions against the spread, loss, and leakage of the solid waste as well as other measures for preventing the solid waste from polluting the environment.

The abandonment or spread of solid waste during transportation is forbidden.

Article 17 Products shall use packing materials which are easily recycled, disposed of, or assimilated by the environment.

http://english.mep.gov.cn/Policies_Regulations/laws/environmental_laws/200710/t200... 2009-10-7 
The product manufacturer, retailer, or consumer shall recycle those product packages and containers that can be recycled in accordance with the relative regulations of the state.

Aticle 18 The state shall encourage scientific research institutions and production units to study and produce thin films for agricultural use that are easily recycled, disposed of, or assimilated by the environment.

Those units and individuals that utilize thin films for agricultural use shall take measures such as recycling to prevent or reduce environmental pollution caused by the thin films. Article 19 The administration and maintenance of the facilities, equipment, and sites for the collection, storage, transportation and disposal of solid waste shall be strengthened in order to guarantee their normal operation and use.

Article 20 It is forbidden to close, disuse, or dismantle without authorization the facilities and sites for preventing environmental pollution caused by industrial solid waste. Those facilities and sites that require closure, disuse, or dismantling must be examined and approved by the administrative departments in charge of environmental protection under the local People's governments at the county level or above, and measures shall be taken to prevent environmental pollution.

Article 21 Those enterprises and institutions that produce solid waste which causes serious environmental pollution shall be ordered to bring their pollution under control within a specified period of time. Those subject to such an order shall accomplish the task on schedule. The order shall be made by the People's government at the county level or above according to the authority granted them by the State Council.

Article 22 It shall be forbidden to construct facilities or sites for the centralized storage and disposal of industrial solid waste or burial sites for residential refuse in nature preserves, scenic spots, historic sites, drinking water sources, and other places of special protection designated by the State Council and the People's governments at the provincial, municipal, or autonomous regional levels.

Article 23 In the event that solid waste is transferred to other provinces, municipalities, or autonomous regions for storage or disposal, a report must be submitted to the administrative department in charge of environmental protection under the People's government of the province from which the solid waste will be transferred, and approval must be granted by the administrative department in charge of environmental protection under the People's government of the province to which the solid waste will be transferred.

Article 24 Within the territory of the People's Republic of China, it is forbidden to dump, pile, or dispose of solid waste from outside the People's Republic of China.

Article 25 The state shall forbid the import of solid waste which cannot be used as a raw material and shall restrict the import of solid waste that can be used as raw material.

http://english.mep.gov.cn/Policies_Regulations/laws/environmental_laws/200710/t200... 2009-10-7 
The administrative department in charge of environmental protection, together with the department in charge of foreign trade and economic cooperation under the State Council shall stipulate, adjust, and announce the list of solid wastes which can be imported for use as raw materials; the import of those kinds of solid waste that are not listed shall be forbidden.

Those that require the import of solid wastes listed in the list stipulated in the preceding paragraph for use as raw materials must acquire approval through examination by the administrative department in charge of environmental protection and the department in charge of foreign trade and economic cooperation under the State Council.

Specific measures shall be formulated by the State Council.

\section{Section 2 Prevention of Environmental Pollution Caused by Industrial Solid Waste}

Article 26 The administrative department in charge of environmental protection together with the department in charge of comprehensive economic affairs under the State Council and other departments concerned shall designate the environmental pollution caused by industrial solid waste, formulate policies on technologies for the prevention of environmental pollution caused by industrial solid waste, and organize the spread of advanced production technologies and equipment for the prevention of environmental pollution caused by industrial solid waste.

Article 27 The department in charge of comprehensive economic affairs together with other departments concerned under the State Council shall organize the research, development, and popularization of production technologies and equipment for reducing the amount of industrial solid waste, and shall promulgate a catalogue of backward production technologies and equipment that are responsible for industrial solid waste resulting in serious environmental pollution and that are to be eliminated within a specified time.

The manufacturer, retailer, importer, or consumer must stop respectively producing, marketing, importing, or utilizing the equipment listed in the catalogue stipulated in the preceding paragraph within the specified time granted by the department in charge of comprehensive economic affairs and other departments concerned under the State Council. The applier of production technologies must cease use of those technologies listed in the catalogue stipulated in the preceding paragraph within the specified time granted by the department in charge of comprehensive economic affairs and other departments concerned under the State Council.

Any equipment required to be eliminated in accordance with the stipulations in the two preceding paragraphs shall not be transferred to others for use.

Article 28 The departments concerned under the People's governments at the county level or above shall formulate a plan for the prevention of environmental pollution caused by industrial solid waste, the popularization of advanced production technologies and equipment for reducing the amount of industrial solid waste, and the promotion of work on the prevention of environmental pollution caused by industrial solid waste.

http://english.mep.gov.cn/Policies_Regulations/laws/environmental_laws/200710/t200... 2009-10-7 
Article 29 Those units that produce industrial solid waste shall establish and amplify a responsibility system for the prevention of environmental pollution and take measures for preventing environmental pollution caused by industrial solid waste.

Article 30 Enterprises and institutions shall rationally choose and utilize raw materials, energy and other resources, apply advanced production technologies and equipment, and reduce the amount of industrial solid waste.

Article 31 The state shall implement a reporting and registration system for industrial solid waste.

Those units which produce industrial solid waste shall present data concerning the volume of waste they produce, its direction of flow, and the methods of storage and disposal to the administrative departments in charge of environmental protection under the People's governments at the county level or above in that locality, in accordance with the regulations of the administrative department in charge of environmental protection under the State Council.

Article 32 All enterprises or institutions which produce industrial solid waste that cannot be utilized, whether at all or temporarily, must, in accordance with the regulations of the administrative departments in charge of environmental protection under the State Council, construct facilities or sites for its storage or disposal.

Article 33 Those who store smelting residue, chemical residue, coal ash residue, discarded ore, tail ore, or other industrial solid waste out of doors shall construct special facilities or sites for its storage.

Article 34 Construction of the facilities and sites for the storage and disposal of industrial solid waste shall be in accordance with the environmental protection standards that have been stipulated by the administrative department in charge of environmental protection under the State Council.

As to those units which produce industrial solid waste before this Law is implemented, if they fail to construct facilities or sites for the storage or disposal of industrial solid waste in accordance with the regulations of Article 32 of this Law, or if the facilities or sites they have already constructed do not conform to environmental protection standards, they shall carry out such construction or reconstruction within a specified period of time. During this time period, waste discharge fees or other measures shall be implemented for any newly produced industrial solid waste from the above mentioned units which pollutes the environment. Those units which complete within the specified time period construction of the facilities or sites for storage or disposal of industrial solid waste, or make them conform with the environmental protection standards through reconstruction, may cease payment of waste discharge fees from the day when the construction or reconstruction is completed. Those units which fail to complete construction before the deadline or which still cannot meet the standards after reconstruction shall continue to pay waste discharge fees until the construction is completed or the standards are met through reconstruction. The relevant specific means shall be stipulated by the State Council. The waste

http://english.mep.gov.cn/Policies_Regulations/laws/environmental_laws/200710/t200... 2009-10-7 
discharge fees shall be reserved for the prevention and amelioration of environmental pollution and shall not be appropriated for any other use.

\section{Section 3 Prevention of Environmental Pollution Caused by Urban Residential Refuse}

Article 35 All units and individuals shall obey the regulations of the administrative departments in charge of environment under urban People's governments by emptying and piling urban residential refuse at designated places. Throwing or piling rubbish outside these designated places is forbidden.

Article 36 The storage, transport, and disposal of urban residential refuse shall, with the purpose of preventing environmental pollution, comply with the regulations of the state concerning environmental protection and urban environment.

Article 37 Urban residential refuse shall be cleared and carried away without delay. Reasonable utilization and neutralization shall be actively conducted.

The separate collection, storage, transport, and disposal of urban residential refuse of different classifications shall be gradually implemented.

Article 38 The urban People's governments shall make plans for improving the fuel structure and developing urban coal gas, natural gas, liquefied petroleum gas, and other clean energy resources.

The relevant departments under the urban People's governments shall arrange for clean vegetables to enter cities to reduce urban residential refuse.

The relevant departments under the urban People's governments shall make comprehensive plans to reasonably arrange a purchasing network and promote the recycling of waste.

Article 39 The urban People's governments shall construct supporting facilities for the cleaning, collection, storage, transport, and disposal of urban residential refuse. Article 40 The construction of the facilities and sites for the disposal of urban residential refuse shall be in accordance with the standards of environmental protection and urban environment stipulated by the administrative department in charge of environmental protection and the department in charge of construction under the State Council.

Unauthorized closure, disuse, or dismantling of the facilities or sites for the disposal of urban residential refuse is forbidden; for those that require closure, disuse, or dismantling, inspection and approval must be made by the administrative department in charge of environmental sanitation as well as the department in charge of environmental protection under the People's governments at the county level or above in that locality; meanwhile, other measures shall be adopted to prevent environmental pollution.

http://english.mep.gov.cn/Policies_Regulations/laws/environmental_laws/200710/t200... 2009-10-7 
Article 41 Those units carrying out construction shall, without delay, remove and dispose of refuse and shall adopt some measures to prevent environmental pollution.

\section{CHAPTER IV SPECIAL STIPULATIONS ON PREVENTION OF ENVIRONMENTAL POLLUTION CAUSED BY DANGEROUS WASTE}

Article 42 The regulations in this Chapter apply to the prevention and cure of environmental pollution caused by dangerous waste. Those not mentioned in this Chapter shall accord with the other regulations of this Law.

Article 43 The administrative department in charge of environmental protection under the State Council shall draw up a national list of dangerous waste in conjunction with relevant departments under the State Council, and stipulate unified differentiating standards, methods, and identification marks for dangerous waste.

Article 44 Identification marks shall be placed on the containers and packing materials for dangerous waste and posted at the facilities and sites for the collection, storage, transport, and disposal of dangerous waste.

Article 45 Those units which produce dangerous waste shall report and register in accordance with the relevant regulations of the state.

Article 46 Those units which produce dangerous waste shall dispose of them in accordance with the relevant regulations of the state. Those who fail to properly dispose of the waste will be required to make rectifications within a specified time period by the administrative department in charge of environmental protection under the People's governments at the county level or above in that locality; as to those units which fail to dispose of the waste before the deadline or which do not carry out disposal in accordance with the relevant regulations of the state, designated units of the administrative department in charge of environmental protection under the People's government at the county level or above in that locality shall undertake to dispose of the waste for them, and all expenses for disposal shall be born by those units which have produced the dangerous waste.

Article 47 The urban People's governments shall organize the construction of the facilities for the centralized disposal of dangerous waste.

Article 48 Those who adopt the disposal method of burying dangerous waste but fail to conform to the regulations of the administrative department in charge of environmental protection under the State Council shall pay waste discharge fees for dangerous waste. The specific means for levying the discharge fees for dangerous waste shall be stipulated by the State Council.

The discharge fees for dangerous waste shall be reserved for the prevention and amelioration of environmental pollution caused by dangerous waste and shall not be appropriated for any other use.

Article 49 Those units which engage in operational activities concerning the collection, storage, and disposal of 
dangerous waste shall submit applications for operational licenses to the administrative department in charge of environmental protection under the people's government at the county level or above. The specific means for doing this shall be stipulated by the State Council.

No unit may engage in operational activities concerning collection, storage, and disposal of dangerous waste without a operational license or fail to be in accordance with the regulations of the license.

No unit may supply or consign dangerous waste to those units without operational licenses to engage in any operational activities concerning collecting, storage, and disposal of dangerous waste.

Article 50 Dangerous waste of different classifications shall be collected and stored separately according to their properties. Mixed collection, storage, transport, and disposal shall be forbidden for different dangerous waste materials which are not compatible and which have not undergone safety processing.

Mixed storage of dangerous waste with non dangerous waste is forbidden.

Article 51 Those who require the transfer of dangerous waste shall fill in forms for the transference of dangerous waste in accordance with relevant state regulations and shall report to the administrative departments in charge of environmental protection under the local People's governments at the county level or above in the area from which the waste is being transferred and in the area which is receiving the waste.

Article 52 Measures for the prevention of environmental pollution shall be adopted during transport of dangerous waste; meanwhile, the state regulations concerning management of the transport of dangerous waste shall be obeyed.

Transport of dangerous waste in a passenger vehicle is forbidden.

Article 53 The sites, facilities, equipment, containers, packagings, and other items used for the collection, storage, transport, or disposal of dangerous waste shall be treated to eliminate pollution before they are diverted for other use.

Article 54 Those workers who will engage in the collection, storage, transport, recycling, and disposal of dangerous waste shall undergo professional training and testing before being assigned such posts.

Article 55 Those units which produce, collect, store, transport, recycle, and dispose of dangerous waste shall draw up emergency measures and preventive measures in the event of accidents, and shall report to the administrative department in charge of environmental protection under the People's governments at the county level or above in that locality, for a relevant examination to be conducted by that department.

Article 56 Those units that cause serious environmental pollution due to accidents or emergencies involving

http://english.mep.gov.cn/Policies_Regulations/laws/environmental_laws/200710/t200... 2009-10-7 
dangerous waste shall without delay take measures to eliminate or decrease the environmental pollution, inform the units or residents that may suffer from the pollution, and report to the administrative department in charge of environmental protection and other relevant departments under the people's governments at the county level or above in that locality and await investigation and handling.

Article 57 The administrative departments in charge of environmental protection under the local People's governments at the county level or above shall report without delay to the People's governments at their own level in the event that dangerous waste seriously pollutes the environment or imperils the security of residents' lives or property. The People's governments shall adopt effective measures to eliminate or decrease the harm.

Article 58 Transit of dangerous waste passing through the territory of the People's Republic of China is forbidden.

\section{CHAPTER V LEGAL LIABILITIES}

Article 59 Those who violate the regulations of this Law by engaging in any one of the following actions shall be required to make rectifications within a specified period of time by the administrative department in charge of environmental protection under the local People's governments at the county level or above and shall be subject to a fine.

(1) failure to report and register industrial solid waste or dangerous waste in accordance with state regulations, or guilt of fraud in reporting or registration;

(2) refusing an on the spot inspection by the administrative department in charge of environmental protection, or guilt of fraud in the course of inspection;

(3) failure to pay waste discharge fees in accordance with state regulations;

(4) transferring to others equipment which has been included in the list of equipment to be eliminated within a definite time;

(5) unauthorized closure, disuse, or dismantling of the facilities or sites for prevention and amelioration of environmental pollution caused by solid waste;

(6) constructing facilities or sites for the centralized storage or disposal of industrial solid waste or the burial sites for residential refuse in nature preserves, scenic spots, historic sites, drinking water sources, or other places which require special protection; or

(7) unauthorized transference of solid waste for storage and disposal out of the administrative territories of their own provinces, autonomous regions, or municipalities directly under the Central Government.

http://english.mep.gov.cn/Policies_Regulations/laws/environmental_laws/200710/t200... 2009-10-7 
Those who engage in actions mentioned in Items 1 or 2 of the preceding paragraph shall be subject to a fine of up to 10,000 yuan; those engaging in actions mentioned in Item 3 of the preceding paragraph shall be subject to a fine of up to 50 percent of the amount of the waste-discharge fees paid; those engaging in actions mentioned in Items 4, 5, 6, or 7 of the preceding paragraph shall be subject to a fine of up to 50,000 yuan.

Article 60 Those who violate the regulations in this Law by producing, selling, importing, or using outmoded equitment or by applying outmoded productive technology shall be required to make rectifications by the department in charge of comprehensive economic affairs under the People's government at the county level or above; if the case is serious, the said department shall submit an opinion to the People's government at the same level and order to terminate business or shut down according to the powers granted by the State Council.

Article 61 For construction projects needing supplementary construction for the prevention and amelioration of solid waste pollution, if the supplementary construction is put into operation or use before being completed or before passing the acceptance inspection, the administrative department in charge of environmental protection which examined the report of the effects of said construction project on the environment shall order production or operation to cease, and may levy a fine of up to 10,000 yuan.

Article 62 If those enterprises and institutions which have been ordered to bring their pollution under control within a specified period of time, do not accomplish the task within the time limit, they shall be subject to a fine of up to 100,000 yuan, to be determined according to the detrimental effects they have caused; or they shall be ordered to terminate business or shut down.

The fine in the preceding paragraph shall be determined by the administrative department in charge of environmental protection, and the order to terminate business and shut down shall be made by the People's government at the county level or above according to the authority granted them by the State Council.

Article 63 Those who violate the regulations of this Law during the storage, transport, or disposal of urban residential refuse shall be penalized according to the State Council's regulations on environmental protection and urban sanitation.

Article 64 Those who violate the regulations in this Law concerning the prevention of dangerous waste pollution, if engaged in any one of the following actions, the administrative department in charge of environmental protection under the People's government at the county level or above shall order to cease said actions and make rectifications within a limited time, and a fine of up to 50,000 yuan shall be levied.

(1) failure to install identification marks for dangerous waste;

(2) supplying or consigning dangerous waste to units that have no operational license for the collection, storage, or disposal of said waste;

http://english.mep.gov.cn/Policies_Regulations/laws/environmental_laws/200710/t200... 2009-10-7 
(3) when transferring dangerous waste, failure to fill in the form for the transference of dangerous waste according to state regulations, or failure to make a report to the administrative department in charge of environmental protection under the People's government at the county level or above either in the area from which the waste is being transferred or in the area which is receiving the waste;

(4) mixed storage of dangerous waste with non dangerous waste;

(5) collecting, storing, transporting, or disposing mixtures of dangerous waste which are not compatible and which have not undergone safety processing;

(6) transportation of dangerous waste in a vehicle carrying travelers or passengers;

(7) failure to dispose of dangerous waste produced or failure to bear disposal fees according to law; or

(8) shifting use of sites, facilities, equipment, containers, packagings, or other items used for the collection, storage, transport, or disposal of dangerous waste without first eliminating all pollutants.

Article 65 For those engaged in the collection, storage, or disposal of dangerous waste without an operating license or in contradiction to the operating license, the administrative department in charge of environmental protection under the People's government at the county level or above shall order the cessation of any illegal activity, confiscate any illegal gains, and may impose a fine of up to the amount of the illegal gains.

Violation of the regulations of the operating license and engaging in the activities of the preceding paragraph may result in the cancellation of the operating license by the license-issuing agency.

Article 66 Those who, in violation of the regulations of this Law, ship solid waste from outside China and dump, store, or dispose of the waste inside the country, and those who import solid waste for use as a raw material without permission from the relevant authoritative department under the State Council, shall be ordered by the customs office to ship the solid waste back, and may be subject to a fine between of 100,000 and $1,000,000$ yuan. Evasion of customs office supervision constitutes smuggling and shall be prosecuted as a criminal act.

Those who, under the pretext of raw materials utilization, import solid waste that cannot be utilized as a raw material shall be penalized according to the regulations of preceding paragraph.

Article 67 Those who, in violation of the regulations of this Law, transport dangerous waste through the territory of the People's Republic of China, shall be ordered by the customs house to ship the dangerous waste back, and may be subject to a fine of between 50,000 and 500,000 yuan.

http://english.mep.gov.cn/Policies_Regulations/laws/environmental_laws/200710/t200... 2009-10-7 
Article 68 For solid waste that enters the border illegally, the administrative department in charge of environmental protection under the People's government at the provincial level or above shall, according to law, submit suggestions for the handling of the waste to the customs office, and the custom office shall make a decision concerning punishment according to Article 66 of this Law. If environmental pollution has been produced, the administrative department in charge of environmental protection under the People's government at the provincial level or above shall order the importer to eliminate the pollution.

Article 69 Those who, in violation of the regulations of this Law, create solid waste pollution, shall be subject to a fine of up to 100,000 yuan by the administrative department in charge of environmental protection under the People's government at the county level or above. If heavy losses have occurred, the fine shall be 30 percent of the direct losses, but shall not exceed 500,000 yuan. The person in charge and other personnel of the polluting unit who have direct responsibility for the losses shall be subject to disciplinary actions by the unit to which they belong, or by the authoritative government department.

Article 70 All fines shall be handed in to the State Treasury, and may not be withheld by any unit or individual.

Article 71 Any unit or person suffering injury from solid waste pollution has the right to demand, according to law, compensation for losses.

Disputes concerning the responsibility for and amount of compensation shall be mediated, at the request of the parties concerned, by the administrative department in charge of environmental protection or other supervisory and administrative departments in charge of the prevention of environmental pollution caused by solid waste. In the case of unsuccessful mediation the parties concerned may present the case to the People's court, or the parties concerned may present the lawsuit directly to the People's court without prior mediation.

Article 72 Those who, in violation of the regulations of this Law, collect, store, or dispose of dangerous waste resulting in serious environmental pollution with serious consequences such as heavy losses to state or private property or personal injury, shall be prosecuted for criminal liability according to Article 115 or Article 187 of the Criminal Law.

Any unit which violates this Article shall be subject to a fine, and the person in charge and other personnel who are directly responsible for the losses shall be prosecuted for criminal liability according the regulations of the preceding paragraph.

Article 73 If the supervisors and managerial staff for the prevention and remedy of solid waste pollution abuse their authority, neglect their duties, play favoritism, or commit irregularities to such a degree as to constitute criminal action, they shall be prosecuted for criminal liability. Those whose actions do not constitute a crime shall be subject to disciplinary action.

\section{CHAPTER VI SUPPLEMENTARY ARTICLES}

http://english.mep.gov.cn/Policies_Regulations/laws/environmental_laws/200710/t200... 2009-10-7 
Article 74 Clarification of terminology included in this Law:

(1) "Solid waste" refers to solid or semi solid waste materials that are produced during production or construction activities, daily life, or other activities, and which pollute the environment.

(2) "Industrial solid waste" refers to the solid waste produced by industry, transportation, etc.

(3) "Urban residential refuse" refers to the solid waste produced in urban daily life, or which results from the activities that serve urban daily life. It also includes those solid wastes that are specified by laws and administrative regulations as urban residential refuse.

(4) "Dangerous waste" refers to the dangerous waste material which is placed on the national list of dangerous waste, or which is specified as dangerous waste by the differentiating standards and methods established by the state.

(5) "Disposal" refers to such activities that burn or alter the physical, chemical, or biological qualities of solid waste so as to reduce the amount and the volume of the solid waste which has been produced, or reduce or eliminate its dangerous components. Disposal also refers to such activities which ultimately deposit, with no intent to reclaim, the solid waste in sites or facilities which meet environmental protection standards.

Article 75 This Law also applies to the prevention of pollution by liquid waste and gas waste which is stored in containers, but not to waste water which is discharged into water, nor to waste gas emitted into the air.

Article 76 If an international treaty concerning protection of the environment against solid waste pollution to which the People's Republic of China is a signatory is at variance with this Law, the former shall be taken as the standard, except for those provisions for which the People's Republic of China has declared reservations.

Article 77 This Law will come into force on April 1, 1996.

Source:

\section{【 Big Medium-sized Small 】 \\ 【Print】【Close】}

Sponsored by MEP, Address: No.115 Xizhimennei Nanxiaojie, Beijing (100035)

Telephone Numbers for Administrative Offices

http://english.mep.gov.cn/Policies_Regulations/laws/environmental_laws/200710/t200... 2009-10-7 